\title{
Pensando na Articulação entre a Internet COMO INSTRUMENTO DE PESQUISA JURÍDICA E O RIGOR ACADÊMICO
}

\author{
Nitish Monebhurrun*
}

\begin{abstract}
1 Introdução. 2 A Internet como fonte moderna de pesquisa jurídica em conformidade com a lógica do rigor acadêmico. $2.1 \mathrm{Um}$ problema $a b$ initio nas fontes de pesquisa, independentemente da Internet. $2.2 \mathrm{Um}$ problema superável, porém agravado pelo uso da Internet como instrumento de pesquisa. 3 Um uso ético da Internet na busca das fontes de pesquisa jurídica para manter o rigor acadêmico. $3.1 \mathrm{O}$ uso ético da Internet decorrente da relação ética do discente com a universidade. $3.2 \mathrm{O}$ uso ético da Internet pelos estudantes oriundo da ética de responsabilidade dos professores. 4 Conclusão. Referências. Anexo A.
\end{abstract}

\section{RESUMO}

Esse artigo propõe uma reflexão sobre o mau uso da Internet como instrumento de pesquisa, o que compromete o rigor acadêmico. Explica-se que o problema não é a Internet como um malefício por natureza, mas as lacunas na formação do(a) jurista que se depara como um mundo de pesquisa sem preparação. Se a Internet facilita consideravelmente o trabalho do(da) pesquisador(a), os problemas de formação e uma ética evanescente na corrida pelo diploma, tornam esse instrumento mais pernicioso. Sustenta-se que a situação emana também da postura dos professores de Direito, que transmitem aos alunos um medo de pensar, ao impor-lhes apenas trabalhos de compilação que não testam a sua capacidade como pensadores do Direito em formação. Ceder à tentação do mau uso da internet, como nos casos de plágio, é uma problemática de cunho ético, mas decorre também da postura dos professores segundo o seu entendimento da docência. Argumenta-se que a ética do aluno durante a sua pesquisa, seja pela Internet ou por qualquer outro meio, é oriunda da ética de responsabilidade do próprio professor.

Palavras-chave: Pesquisa. Formação do jurista. Internet. Rigor acadêmico.

* Doutor em Direito Internacional (Escola de Direito de Sorbonne, Paris, França); Professor de Direito (Programa de Graduação e de Pós-Graduação, Centro Universitário de Brasília, Uniceub, Brasília, Brasil); Professor Visitante (Programa de Mestrado em Direito Internacional, Universidade da Sabana, Bogotá, Colômbia; Escola de Direito, Paris, França.). E-mail: <nitish.monebhurrun@gmail.com>. 


\section{INTRODUÇÃO}

A presente reflexão surgiu da inquietação atinente ao emprego da Internet nas atividades de pesquisa e nos trabalhos universitários com a constatação de que, não raro, esse novo instrumento de pesquisa é utilizado com falta de rigor acadêmico. Esse artigo examina como esse problema é, de uma forma mais profunda, um sintoma das lacunas na formação do jurista.

A Internet, como veículo de informações, tornou-se uma fatalidade. Os mais reacionários adotaram-na, vez que os tentáculos do international network invadiram todas as esferas do cotidiano. Habitualmente, a Internet define-se como o espaço virtual constituído em redes informáticas que relacionam aparelhos informáticos no mundo afora ${ }^{1}$. Ora, essa definição simples revolucionou o âmbito complexo das ciências - exatas, sociais, humanas — notadamente, no que tange à pesquisa científica e à necessária adaptação do pesquisador. No plano do Direito e no mundo dos juristas, a Internet facilitou seguramente o acesso à informação técnica, atuando como uma fonte en vogue para a pesquisa jurídica.

A fonte de pesquisa jurídica é a matéria-prima do jurista, isto é, os textos normativos - Constituição, lei, tratado... - , os costumes, os princípios gerais de direito, a jurisprudência, os relatórios e os dados oficiais, as informações atinentes aos estudos de campo e a doutrina. A Internet apresenta-se como uma plataforma, como um instrumento, que proporciona o acesso a essas fontes de pesquisa jurídica; ela atua como uma fonte para pesquisar as - e nas - fontes do Direito. Logo, por um lado, ela torna o Direito mais acessível; por outro, ela peca por sua opulência, que oferece um mar de informações e de dados sem que exista sempre uma pormenorização, uma classificação rigorosa ou um rigor científico. A Internet é também sinônimo de facilidade e de rapidez: é um instrumento que diminuiu consideravelmente o tempo dedicado à pesquisa, ao fornecer chaves para abrir frentes outrora inacessíveis. Entrementes, todas as informações disponibilizadas na Internet não seguem o mesmo padrão de qualidade e de excelência quanto a sua elaboração. Não basta saber ler um artigo com o olhar do jurista; é, outrossim, importante, saber escolher o artigo (ou o texto) cientificamente confiável no turbilhão de artigos (ou de textos) disponíveis. Por exemplo, o Google é, deveras, uma faca de dois gumes, um dos quais convida à facilidade e serve, às vezes, para cortar o rigor e o espírito crítico do pesquisador. Não seria exagerado dizer que muitos professores de Direito já se depararam com trabalhos cuja referência principal é aquele primeiro texto que se encontra no Google ao se fazer uma pesquisa básica com as palavras-chave do tema objeto do estudo. $\mathrm{O}$ mesmo comentário aplica-se àqueles artigos cuja inspiração é o Wikipedia, um blog de informação e de opinião, ou outros sites que disponibilizam artigos que não passam por uma avaliação científica rigorosa.

Ao preparar esse estudo, o presente autor enviou um questionário com cinco perguntas aos professores de algumas faculdades de Direito, assegurando-se de uma amostra geograficamente representativa. Essas perguntas foram: 1) Os alunos sabem fazer uma pesquisa jurídica científica na Internet? Isto é, 
sabem buscar as fontes de pesquisa (textos normativos, jurisprudência, relatórios e pareceres, doutrina) nos sites oficiais?; 2) Em referência aos artigos doutrinários, as fontes mais consultadas são as revistas científicas pontuadas?; 3) Há uma tendência de abusar da Internet durante a pesquisa ao escolher os portais de "facilidade" (wikipedia, blogs, Jus Navigandi)?; 4) Os alunos sabem dissociar entre artigos oriundos de um trabalho rigoroso de pesquisa e de reflexão e artigos superficiais?; 5) Os alunos são devidamente informados/formados para poder utilizar a Internet como um instrumento de pesquisa?. As respostas encontram-se no Anexo $1^{2}$.

Por óbvio, não é um espelho cristalino da realidade: os(as) professores(as) e colegas que responderam ao questionário expressaram sobretudo a sua experiência, a sua vivência e a sua opinião pessoal, o que não é generalizável à instituição à qual eles / elas pertencem e, a fortiori, a todas as outras universidades brasileiras. Utilizando o questionário mais como um tipo ideal, o objetivo era verificar se algumas inquietações são divididas por outros professores de Direito, em outros Estados do Brasil, no que tange ao uso da Internet como um instrumento de pesquisa. Logo, o questionário limita-se apenas a essa constatação, e ajuda, potencialmente, a situar o leitor/a leitora, sem ter qualquer outra pretensão científica. As conclusões da presente reflexão não decorrem das respostas disponíveis no questionário. Trata-se aqui de um alerta metodológico importante para os leitores.

Opulência, facilidade, informações, dados, pesquisas e trabalhos já prontos e já mastigados: eis o que também acompanha em filigranas a aura da Internet quando esta é utilizada como um meio para pesquisar. Logo, grande pode ser a tendência do discente de ceder à tendência da facilidade. A Internet domina um mundo que anda a uma velocidade altíssima, mas com um tempo de respiração curto e, com um mau uso, pode desregular o mesmo mundo que ela pretende regular. E disso decorre a postura ética esperada do universitário: a sua seriedade ao usar a tecnologia.

O rigor acadêmico entende-se como a integridade e a honestidade intelectual. Está embutido no que Max Weber chama de vocação do universitário ${ }^{3}$, isto é, aquele que tem a postura de contribuinte à ciência e não de usurpador; aquele que se esforça para erguer um pensamento próprio sem apropriar-se das obras de outrem. O universitário vocacional está a serviço da universidade e não coloca a universidade a seu serviço. A sua postura é a do/da cientista do Direito: ele/ela pesquisa para contribuir com o avanço da reflexão para a prática ou a teoria do Direito; calibra a pesquisa para que sirva às problemáticas jurídicas concretas. Todos os seus esforços são canalizados nesse sentido. Para tanto, os resultados que se esperam dele/dela devem, imprescindivelmente, decorrer de uma pesquisa séria.

Malgrado, o rigor acadêmico é facilmente testado e desafiado defronte à Internet como instrumento de pesquisa cada vez mais privilegiado. Tornou-se o horizonte inultrapassável no processo de pesquisa, muitas vezes em detrimento 
das próprias bibliotecas. $\mathrm{O}$ virtual e o numérico conquistaram um espaço indubitável na pesquisa, e os juristas em formação se depararão cada vez mais com a abundância que caracteriza a Internet como fonte de informações torrenciais. É uma fatalidade com a qual se deve conviver e a coexistência deve ser a melhor, a mais produtiva. Logo, trata-se de algo cuja utilização deve ser controlada ao ser conjugada com a pesquisa rigorosa. Destrinchar o seu objeto de pesquisa pelo pensamento para construir um trabalho rigoroso deve ser articulado com a facilidade que se tem hoje em fazer uma pesquisa apenas pelo googling. A Internet deve estar a serviço da pesquisa e não ser um instrumento suspeito. Isso se torna possível a depender da postura do pesquisador.

Dessa feita, a problemática que emana dessas considerações é de saber se a Internet, como instrumento de pesquisa, prejudica o rigor acadêmico na determinação das fontes de pesquisa.

A isso responde-se pelo negativo, pois a Internet é indubitavelmente uma fonte moderna de pesquisa jurídica que está em conformidade com a lógica do rigor acadêmico (Tópico 2), considerando que um uso ético desse instrumento seja feito (Tópico 3).

\section{A INTERNET COMO FONTE MODERNA DE PESQUISA JURÍDICA EM CONFORMIDADE COM A LÓGICA DO RIGOR ACADÊMICO}

Ab initio, independentemente do uso da Internet, há um problema nas próprias fontes de pesquisa na academia jurídica brasileira (2.1.), e, até certo ponto, esse problema é superável pelo uso dessa tecnologia (2.2.).

\subsection{UM PROBLEMA AB INITIO NAS FONTES DE PESQUISA, INDEPEN- DENTEMENTE DA INTERNET}

No uso dos instrumentos de pesquisa clássicos ou modernos, percebe-se que os alunos não são incitados a atuar e a pensar como juristas, com uma mente independente e com uma vontade de pensar. Foi estabelecida uma inversão na ordem da pesquisa, dando um valor profético à doutrina. Há uma tendência de considerar os textos doutrinais (manuais, livros e artigos) como a fonte principal e primária de pesquisa. A matéria-prima do Direito, como a lei, a Constituição, os tratados ou, às vezes, o próprio conhecimento de pesquisa de campo são relegados a uma posição secundária - o que ocorre também com a jurisprudência e a sua análise crítica. Pensa-se que respostas prontas encontram-se na doutrina e tem-se a impressão de que o núcleo normativo e jurisprudencial é um artifício ${ }^{4}$. Não se trabalha com o Direito bruto. Assim, os alunos são incitados a confundir a sua opinião com aquela da doutrina; em outras palavras, são incitados a ver na doutrina um oráculo indefectível, dono da verdade, e defronte do qual eles devem se prosternar como fâmulos, num ato de sujeição, o que adormece a sua capacidade de refletir e de se expressar por si só, sem uma muleta doutrinal. ${ }^{5}$ 
Sendo assim, os alunos nunca encontram a sensação contrariada cara a Cioran, como uma fonte e como uma razão do pensamento próprio ${ }^{6}$; pois, ao serem tratados como autômatos, os alunos não desenvolvem o senso crítico mínimo para serem intelectualmente contrariados nas suas leituras e na sua formação como jurista. Contrariar aqui significa dar-se a possibilidade de não concordar e de poder manifestar essa discordância com argumentos próprios. Ou como diria um outro autor - num outro contexto similar ao presente "lhe[s] falta a capacidade para hesitar", assim como essa capacidade falta às máquinass. A formação do jurista não proporciona um tempo suficiente para que ele/ela possa contemplar com calma o seu próprio pensamento, a sua própria opinião ${ }^{8}$; ele/ela, especialmente no nível da graduação, não está preparado/a para expressar tecnicamente e defender metodologicamente sua opinião ${ }^{9}$. A sua educação é meramente "um ato de depositar" e os alunos são os "depositários", como diria Paulo Freire ${ }^{10}$. Portanto, eles/elas começam a acreditar que não têm a habilitação ou a permissão para refletir. E com o passar do tempo, aceitam a ideia de que o não pensar é a segunda natureza do aluno de Direito ${ }^{11}$. A sua opinião torna-se apenas aquela dos outros, cujas obras eles são incitados a ler ou a ingurgitar. Não se desenvolve a capacidade de problematizar o Direito - o primeiro passo para poder pensar o Direito.

Admite-se assim, escancaradamente, a derrota do pensamento: a individualidade dos alunos - e logo do seu pensamento - não é expressada, pois não são levados a superar "a tirania das ideias preconcebidas"; ${ }^{12}$ ficando muitas vezes na trivialidade. Essa realidade se deve aos professores acomodados, que os ensinam a não pensar, ou que lhes ensinam que o ato de pensamento é liberado apenas no doutorado e que toda reflexão pessoal está condenada antes disso ${ }^{13}$. É a transmissão de um medo de pensar. O que dizia outrora Schopenhauer (século XIX) é ainda de uma infeliz atualidade:

Os professores ensinam para ganhar dinheiro e não se esforçam pela sabedoria, mas pelo crédito que ganham dando a impressão de possuí-la. E os alunos não aprendem para ganhar conhecimento e se instruir, mas para poder tagarelar e para ganhar ares de importantes. A cada trinta anos, desponta no mundo uma nova geração, pessoas que não sabem nada e agora devoram os resultados do saber humano acumulado durante milênios, de modo sumário e apressado, depois querem ser mais espertas do que todo o passado. ${ }^{14}$

Cria-se o discente cego e mudo. E com as mesmas características, o mesmo aluno/a mesma aluna pesquisa - perigosamente - as suas fontes supostamente técnicas, na Internet, para elaborar o seu trabalho, ora, sem saber separar o joio do trigo. Logo, por não ter o treinamento suficiente desde a graduação e por não estar habituado a ter esse senso crítico, a pesquisa na Internet - particularmente por muitos alunos da graduação -, não discrimina entre o artigo científico rigorosamente construído e os outros. Tudo vale: da tese de doutorado ao blog de opinião. 
Portanto, há um problema grave no próprio método de pesquisa básica a montante mesmo de qualquer problema atinente às novas tecnologias. É esse problema - prioritário - que deve ser resolvido antes de qualquer outro. Os alunos não devem ser tratados como seres incapazes de reflexão e a graduação é o lugar para que eles se construam como seres pensantes sob a supervisão do professor $^{15}$ - o que implica que eles errem várias vezes e que sejam corrigidos tantas vezes até lograr formular um pensamento crítico autônomo. Isso é de suma importância, pois para ser um bom operador do Direito é preciso ser um pensador afiado do Direito. Outrossim, é um processo de aprendizado que esculpe o cidadão consciente. ${ }^{16} \mathrm{O}$ artigo 205 da Constituição Federal do Brasil dispõe que o papel da educação é, entre outros, a formação do cidadão, o que se faz com alguns corolários básicos que são a divulgação do pensamento e do saber, conforme a mesma Carta Magna. ${ }^{17}$ É nesta confluência que se destila, em parte, o rigor acadêmico: incitar os alunos a pensar com verde idade diminui o risco de mau uso dos novos instrumentos de pesquisa, como a Internet.

Dito isso, e considerando a internet como uma fatalidade com a qual é preciso conviver, é possível utilizar esse meio para superar o problema descrito nessa parte.

\subsection{UM PROBLEMA SUPERÁVEL, PORÉM AGRAVADO PELO USO DA INTERNET COMO INSTRUMENTO DE PESQUISA}

O problema é superável porque a Internet disponibiliza - com fácil acesso, com baixo custo e com grande variedade - , uma parte importante do material útil para a pesquisa jurídica. Antigamente, era bem mais complicado ter um acesso livre e permanente às coletâneas de leis ou de jurisprudência ou de livros e outros documentos, sobretudo em línguas estrangeiras. No Brasil, parte da doutrina critica a falta de referência à jurisprudência ${ }^{18}$ e à doutrina estrangeira ${ }^{19}$ nos trabalhos jurídicos. Entretanto, vários programas elaborados especificamente para a pesquisa jurídica online permitem contornar esse problema na pesquisa. Hoje em dia, quase todas as decisões dos tribunais - no nível nacional ou internacional - encontram-se disponíveis online, no próprio website dos órgãos jurisdicionais. Há, na mesma toada, uma miríade de programas ou de portais que permitem um acesso fácil e rápido - gratuito ou disponível por meio das bibliotecas - aos textos doutrinais estrangeiros ou nacionais. A título de exemplo, é possível citar: Scielo, Isis Web of Science, HeinOnline, Westlaw, LexisNexis, o próprio Social Science Research Network, o New Journal da Universidade de Georgetown, o EbscoHost, o Directory of Open Access Journals, o Portal periódicos CAPES, o Directory of Research Journals Indexing, o WorldCat, a Biblioteca Online do Conselho de Justiça Federal, a Academia.edu, entre outros. Aliás, várias revistas jurídicas dispõem de uma edição virtual gratuita, com uso facílimo. Sendo assim, o material básico de pesquisa está disponível online e, nesse sentido, a Internet é nada menos que uma biblioteca virtual que se coaduna com a biblioteca física. Dito isso, a disponibilidade de informações e 
a possibilidade de uma conexão regular à Internet não significa que estas são devidamente consultadas e aproveitadas. Por exemplo, muitas teses de doutorado em Direito sequer se referem aos periódicos disponíveis gratuitamente na Internet ${ }^{20}$. Preferem-se - em todos os níveis, da graduação ao doutorado —, outros portais de pesquisa como o Jus Navigandi, cuja seriedade é às vezes duvidosa, por não haver uma fiscalização rigorosa e minuciosa da qualidade e do teor dos artigos ali publicados. ${ }^{21}$

É interessante notar, por um lado, a Internet como um reservatório riquíssimo de dados e de informações para o jurista ${ }^{22}$ e, por outro, a sua exploração ineficiente para a pesquisa. Uma das razões para tanto é que os alunos não são formados para serem pesquisadores. Isto porque muitos Professores de Direito não são pesquisadores. ${ }^{23}$ E sobre esse ponto, deve ser desmentido o mito segundo o qual há a prática por um lado e a pesquisa por outro. Para atuar séria e cabalmente em qualquer âmbito do Direito é, na maioria dos casos, imprescindível ser um bom pesquisador. Do advogado ao procurador, ao juiz, ao professor, ao consultor, todos devem, no âmbito do seu trabalho, procurar um volume importante de informações de cunho jurídico - ou não jurídico - para sustentar a sua argumentação, a sua decisão, a sua tese, o seu parecer. Dominar o passado e a atualidade de todas as fontes jurídicas aplicáveis para o entendimento de um determinado problema jurídico demanda uma dedicação considerável à pesquisa. Ademais, saber encontrar as informações certas, saber fazer um filtro seletivo na torrente de informações disponíveis requer uma qualidade, uma capacidade e, destarte, uma formação de pesquisador. É só dessa forma que se adquire o domínio orgânico do tema e o conforto intelectual suficiente para tratar seriamente de um assunto jurídico e de uma problemática jurídica. Ou seja, a pesquisa não se atrela apenas às atividades científicas universitárias. Por isso, a pesquisa requer uma formação real como pesquisador - o que não é devidamente proporcionada pela maioria das universidades. Por costume, os alunos começam cedo as atividades de estágio, seja nos escritórios de advocacia ou junto aos órgãos públicos; tão cedo, que chegam a esse mundo sem uma devida preparação técnica de pesquisador. E a pesquisa é uma das atividades principais do estagiário. Como os alunos passam um tempo considerável estagiando durante a sua vida de estudante, eles não logram dedicar-se suficientemente ao aprendizado dos métodos de pesquisa e do raciocínio jurídico - a parte, indubitavelmente, mais importante na preparação do jurista. Ora, estes devem ser ensinados na universidade, e logo a partir do primeiro ano, e não no final do curso. Não é algo que se aprende facilmente em campo.

O problema é que a grande e, às vezes, a única atividade de pesquisa para os alunos da graduação em Direito é a monografia, atividade com a qual eles se deparam repentinamente quase no final de sua formação. É também o momento mais tumultuado, por ser simultâneo à preparação para o Exame da Ordem. Por conseguinte, talvez não seja o melhor momento para ensinar aos alunos o passo a passo da pesquisa de forma geral, e, de forma particular, pelo instrumento da Internet: a realidade fria é que, nesse momento, muitos 
querem apenas terminar o curso. Por isso, o trabalho de pesquisa na graduação conta, no melhor dos casos, com um mau uso - e no pior, com um abuso da Internet, o plágio sendo, por exemplo, uma consequência patológica típica disto. A Internet é, nesse caso, utilizada como uma facilidade e como um recurso que, na mente de alguns, oferece respostas prontas, utilizáveis para poupar ou contornar os esforços que deveriam embasar um trabalho sério. Em vez de ser utilizada de forma plena, mas cuidadosa, como um novo instrumento sofisticado e potente de pesquisa, a Internet tornou-se um servidor domesticado pela facilidade dominante e pela ética evanescente.

De forma alguma, isso significa que a Internet deva ser banida ou limitada como meio de pesquisa. É mais razoável propor um uso ético desse instrumento incontornável para atender ao esperado rigor acadêmico.

\section{UM USO ÉTICO DA INTERNET NA BUSCA DAS FONTES DE PESQUISA JURÍDICA PARA MANTER O RIGOR ACADÊMICO}

Se a ética deve ser oriunda do próprio discente (2.1), depende-se fortemente de um enquadramento e de um fulcro institucional — das universidades e dos professores - para efetivá-la (2.2.).

\subsection{O USO ÉTICO DA INTERNET DECORRENTE DA RELAÇÃO ÉTICA DO DISCENTE COM A UNIVERSIDADE}

De forma ideal-típica, é possível fazer um paralelismo entre a relação que o/a discente tem com a universidade e a postura que ele/ela mostra nos seus trabalhos de pesquisa, inclusive, pelo uso da Internet para tais fins. Estudos demonstram que algumas tendências perceptíveis na postura dos discentes na universidade tornam propício o uso sem ética da Internet como instrumento de pesquisa: são, por exemplo, a ausência de dedicação e de vocação para com os estudos, a desorganização pessoal na preparação dos trabalhos, o valor que se dá à busca e à construção do pensamento próprio ou à consciência de sua formação efetiva como um/uma profissional responsável, confiável, sério/a, e competente no futuro. ${ }^{24} \mathrm{Em}$ outras palavras, dá-se à pesquisa o mesmo valor que se confere à universidade e aos estudos. Por exemplo, a grande preocupação de muitos alunos com os concursos públicos - o horizonte intransponível do Direito no Brasil —, torna-os às vezes recipientes fáceis de uma educação à la carte, de uma formação mecânica cuja meta é precipuamente um certificado, e nem sempre a consciência de se tornar um jurista competente, rigoroso, eficiente e responsável. Quando a Internet se apresenta nesta configuração, é esperado que o seu uso não seja sempre ético.

A ética, no presente entendimento, é a postura intelectual pela qual o/a discente impõe-se um dever de conduta, de retidão, ao engajar-se a atuar com honestidade na execução dos diversos trabalhos e exercícios a ele/ela solicitados durante a sua formação. É um compromisso de se esforçar para 
apresentar trabalhos que contenham uma pesquisa própria e reflexão próprias. Certamente, inspira-se de outrem, porém sem apropriar-se das ideias ou das palavras deste/desta. Essa virtude intelectual não é nata, mas ela se aprende e se cultiva pela prática. ${ }^{25}$ Ser ético(a) é uma postura e implica, portanto, uma escolha: a virtude intelectual é um caminho que deve ser deliberadamente escolhido pelo livre-arbítrio. ${ }^{26}$ Não se impõe uma postura ética ao discente: é algo que se incorpora, que se desenvolve e que se pratica até que se torne uma forma de ser. E, para alcançar isso, são, às vezes, necessárias poucas coisas como, por exemplo, acostumar-se a um repouso mental e a um tempo de reflexão ${ }^{27}$ e de contemplação, de otium, ${ }^{28}$ suficiente para pensar no seu papel como aluno(a) e na sua função como jurista em formação. Pensa na ética aquele(a) que tem tempo para pensar. Talvez seja aqui uma lacuna dos estudos universitários modernos: não proporcionar um tempo adequado para esculpir o pensamento próprio, não dissociar o tempo da leitura e dos estudos daquele da construção do pensamento. $O$ frenesi ou o cansaço da sociedade ${ }^{29}$ se importa e se repete nas universidades, que raramente enxergam esse lado da formação, ao se focarem mormente na preparação técnica dos discentes.

Quando essa realidade se articula com o mundo da pesquisa, a grande dádiva que pode ser a Internet, para o(a) pesquisador(a), torna-se facilmente um malefício. Convida, às vezes, a um uso fácil, sem esforço e sem ética da Internet. Para o discente desatento ou despreocupado ou até desorganizado, a Internet é uma tentação. É uma ferramenta que passa uma forma de confiança aos usuários por lhes dar a quase certeza de que a informação buscada estará, em princípio, facilmente disponível, logo, utilizável. E na confluência entre o volume de informação efetivamente disponível e uma falta de preparação como pesquisador ético, pode nascer uma tendência de confundir pesquisa e apropriação: a prática do plágio corrobora isso.

No Brasil, a legislação sobre os direitos autorais dispõe que é passível de danos morais quem "na utilização, por qualquer modalidade, de obra intelectual, deixar de indicar ou de anunciar, como tal, o nome, pseudônimo ou sinal convencional do autor e do intérprete [...]." 30 O Supremo Tribunal de Justiça, referindo-se na realidade à doutrina, entende o plágio como "tanto assinar como sua obra alheia, como também imitar o que outra pessoa produziu. O plágio pode dar-se de maneira total (copiar ou assinar como sua toda a obra de terceiro) ou parcial (copiar ou dar como seus apenas trechos da obra de outro autor)." ${ }^{11}$ Num sentido similar, o Conselho Nacional de Desenvolvimento Científico e Tecnológico (CNPq) explica que o plágio:

[...] consiste na apresentação, como se fosse de sua autoria, de resultados ou conclusões anteriormente obtidos por outro autor, bem como de textos integrais ou de parte substancial de textos alheios sem os cuidados detalhados nas Diretrizes. Comete igualmente plágio quem se utiliza de ideias ou dados obtidos em análises de projetos ou manuscritos não publicados aos quais teve acesso como consultor, revisor, editor, ou assemelhado. ${ }^{32}$ 
Embora não exista uma definição universalmente aceita do plágio, ${ }^{33}$ boa parte da doutrina o reconhece como sendo uma apropriação, sem referências ou citações, por um autor, do texto ou da ideia (escrita) de outrem, deixando os leitores acreditarem que é oriundo da sua própria autoria. ${ }^{34}$ Se é incontestável que o plágio existia antes da era digital ${ }^{35}$ é, outrossim, indubitável que o fenômeno tende apenas a se agravar com o uso da Internet, que facilita muito as possibilidades de 'cópia e cola'. Ora, o objeto desse estudo não é em si o plágio: ${ }^{36}$ a questão do plágio se enquadra na presente reflexão para demonstrar um problema na formação dos discentes que não estão sempre preparados para assumir eticamente o trabalho de pesquisa. Reina uma certa arbitrariedade, pois se parte do princípio de que os alunos já têm ou já devem ter uma carga ética oriunda de outros componentes ou de outros momentos de sua educação.

A crítica aqui não é de cunho moral, mas sim de índole social. Não se julga moralmente a questão da ética: conforme visto, basta constatar que o plágio, como ato antiético, é algo jurídica e institucionalmente condenado. Entrementes, ter uma postura ética na universidade e na pesquisa não significa ter apenas um engajamento consigo mesmo. Não é apenas uma ética do tipo minimalista de autossatisfação e de boa consciência, oriunda de uma boa conduta ou de boas práticas. ${ }^{37}$ A ética do universitário — docente ou discente - é uma ética de responsabilidade, consequencialista. ${ }^{38}$ Os juristas em formação são, por assim dizer, 'inofensivos', quando praticam atos de plágio dentro dos muros das faculdades de Direito. Não obstante, eles terão amanhã, como advogados, juízes, professores, promotores e procuradores, técnicos e servidores, a mesma relação com a ética que têm hoje como discentes. Inexiste, às vezes, uma ética de responsabilidade, pois os alunos em formação têm como único alvo o diploma, independentemente do caminho que devam percorrer. Não se pensa que a formação atual é de suma importância para determinar como os juristas formados exercerão futuramente a sua função para o interesse da sociedade na qual vivem; numa lógica individualista, não se pensa nas consequências que uma formação aproximativa, incompleta ou medíocre pode ter como repercussão social. A ultra-leveza ou a dedicação titubeante que caracteriza a desonestidade nos trabalhos universitários e que tipifica o mau uso da Internet como fonte de pesquisa anuncia o tipo de profissional que será formado. Outrossim, um jurista em formação que se acostuma a não ter o cuidado metodológico para verificar as suas fontes ou que adota intencionalmente o plágio como forma de elaborar os seus trabalhos seguramente não será um profissional confiável: não se pode confiar num jurista que não respeita a lei. Fazer mau uso da Internet ao ceder ao plágio é, além de um problema ético, o sintoma de um mal-estar nas faculdades de Direito. Parece que se forma o discente só para ele/ela. Talvez as universidades não insistam suficientemente na formação dos alunos para — também — servir aos interesses da sociedade. Um certo individualismo que já se irradiou pela sociedade descolorou-se também nas universidades. Os alunos não são realmente instigados a pensar na razão de ser de sua presença na universidade. A formação valoriza sobretudo a individualidade. Nas universidades públicas, eis algo ainda 
mais grave, vez que os alunos estudam — e tem a possibilidade de estudar — às custas da sociedade. Mas, independentemente da origem da universidade, faz justamente parte da ética de responsabilidade pensar que uma formação atual deve permitir uma retribuição direta ou indireta futura à sociedade. Eis aqui também uma função das instituições de ensino e dos professores que devem oferecer um enquadramento sólido para que se respeite uma certa retidão ética na formação dos alunos. A ética de responsabilidade destes dimana da ética de responsabilidade dos seus mestres.

\subsection{O USO ÉTICO DA INTERNET PELOS ESTUDANTES ORIUNDO DA ÉTICA DE RESPONSABILIDADE DOS PROFESSORES}

É claro que ter uma aula sobre a ética não torna repentinamente o(a) aluno(a) mais ético(a), ${ }^{39}$ capacitando-o(a) para fazer um uso ético da Internet. O processo para esse fim é não só pedagógico, mas também duradouro. Emana, na realidade, da própria ética de responsabilidade dos professores.

Alguns autores, com os quais concorda-se plenamente, propõem um controle ético do tipo formal: refletem nas modalidades institucionais e formais para prevenir, punir e combater o plágio. Propõem, nesse sentido: a adoção e a divulgação de códigos de condutas para os discentes, a constituição de comissões específicas para julgar casos de plágio, a utilização de programas informáticos para detectar o plágio, o condicionamento do depósito de um trabalho universitário por uma declaração de autenticidade..$^{40}$ As diretrizes do CNPq sobre a integridade nos trabalhos científicos seguem uma lógica similar. ${ }^{41}$ São, sem dúvida, possibilidades para prevenir o mau uso do mundo digital para elaborar trabalhos científicos. É uma forma de conscientizar os alunos e de frisar a gravidade que caracteriza os atos de plágio.

Embora louváveis e necessárias, essas propostas e medidas não são suficientes. Não influenciam muito a essência do problema e, até certo ponto, podem equiparar-se a um policiamento dos trabalhos universitários - o que, na realidade, já se tornou uma prática comum e infeliz.

Sustenta-se aqui que o uso ético da Internet - e, de forma geral, a postura ética dos estudantes - decorre da ética de responsabilidade dos professores. Até certo ponto, o discente é o espelho do docente. Destarte, defende-se que a essência do problema apresentado ao longo desse trabalho obterá um tratamento adequado e substancial apenas se a capacidade de pensamento e de reflexão pessoal dos alunos não for sufocada, paralisada ou imobilizada pelos próprios professores. É responsabilidade ética do professor instigar, forçar, extrair o pensamento dos estudantes, logo a partir do primeiro ano da faculdade. Por causa de alguns professores, os alunos são mal acostumados a um mimetismo acadêmico pelo qual são incitados a compilar as ideias de outrem e a reverenciar determinados autores,${ }^{42} \mathrm{sem}$ ter a possibilidade de construir o seu próprio pensamento. Malgastam assim gerações de recursos humanos. Impõem-se nas faculdades 
de Direito trabalhos jurídicos cujo objeto é compilar a doutrina. Substitui-se a crítica pela complacência. Ter as premissas de uma reflexão pessoal parece um tabu e muitos professores acomodaram-se com a ideia de que o(a) graduando(a) ou até o(a) mestrando(a) é, quase por natureza, inapto(a) a pensar por si só ou a ter um espírito crítico. Não se pensa que são esses estudantes que serão os juristas - e eventuais professores - no futuro e que não se pode deixar entrar no mundo profissional alguém que não sabe pensar o Direito. Tampouco se pensa que um estudante não acostumado ao exercício do pensamento pode mais facilmente ceder à tentação de apropriar-se dos trabalhos ou das ideias de outrem ou que ele/ela não fará necessariamente uso inteligente e sábio dos instrumentos de pesquisa, como a Internet. Ajudar os estudantes a esculpir o seu pensamento significa também erigir barragens contra práticas não éticas na universidade e na prática profissional ulterior: se, desde cedo, todos os trabalhos requisitados aos estudantes tivessem como objetivo a busca da opinião técnica e argumentada deles, o fato de poder erguer um pensamento próprio sobre uma determinada problemática jurídica tornar-se-ia um reflexo intelectual normal no decorrer do tempo da formação. Essa valorização da opinião pessoal permite uma autoestima racionalizada e afasta potencialmente os alunos da tendência de se apropriarem das obras dos outros, ensinando os alunos a respeitar os escritos dos autores. Além disso, confere-lhes a maturidade suficiente para fazerem um uso mais crítico das informações oriundas da Internet.

Ora, é bem verdade que assumir essa função requer uma dedicação maior e um trabalho considerável da parte do corpo docente, pois demanda um acompanhamento permanente dos alunos ${ }^{43}$ e exige uma correção minuciosa de seus trabalhos para averiguar a formação e a consolidação da sua capacidade de pensar científica e criticamente. Depende também, por óbvio, da orientação e do método de ensino de cada instituição, mas em um nível micro, são os professores que têm um papel determinante. Pensar o Direito, assim como ensinar a pensar o Direito, são, em si, uma profissão. Calibrar a mente dos alunos, explicar as técnicas e os métodos de raciocínio jurídico, ensinar como (e por quê) separar as predisposições ou os preconceitos ideológicos da tecnicidade, tudo isso requer uma articulação permanente entre docentes e discentes. É também essa presença forte do professor que pode evitar a ubiquidade descontrolada da Internet e o seu uso pernicioso.

\section{CONCLUSÃO}

Percebe-se, portanto, que a Internet não é, por natureza, um instrumento duvidoso para a pesquisa jurídica. Num mundo universitário desleixado, caracterizado pela ausência de pensamento, torna-se um instrumento que tem a capacidade de dominar, de subjugar os alunos. No entanto, num âmbito universitário governado pela primazia e pelo esforço da reflexão, são os próprios alunos que conseguiriam domar esse instrumento e colocá-lo a serviço da pesquisa. Uma das condições para tanto é a presença do professor durante o 
processo de formação, a qual não deve sufocar o(a) aluno(a), ocupando todo o seu espaço, mas para ajudá-lo(a) a saber pensar. Para afiar a postura ética dos estudantes, sustenta-se que é a ética do ensino do Direito que deve ser revista para estimular um ser pensante em cada aluno(a).

\section{REFERÊNCIAS}

ALMEIDA, Paulo Roberto de. Falácias acadêmicas, 3: o mito do marco teórico. Revista Espaço Acadêmico, Maringá, n. 89, 2008.

ARISTÓTELES. Éthique de Nicomaque. Paris: GF-Flammarion, 1992.

BAST, Carol M.; SAMUELS, Linda B. Plagiarism and Legal Scholarship in the Age of Information Sharing: the Need for Intellectual Honesty. Catholic University Law Review, United States, v. 57, n. 3, p. 777- 815, 2008.

CIORAN, Emil Michel. De l'inconvénient d'être né. Paris: Gallimard, 1973.

DUNNEWOLD, Mary. Plagiarism: Proceed with Caution. Student Lawyer, v. 40, n. 1, 2011.

FINKIELKRAUT, Alain. La défaite de la pensée. Paris: Gallimard (Folio-Essais), 1987.

FREIRE, Paulo. A pedagogia do oprimido. 17. ed. Rio de Janeiro: Paz e Terra, 1987.

GOUDY, Henry. Plagiarism: a Fine Art. The Juridical Review, v. 20, p. $302-$ 315, 1909.

HAN, Byung-Chul. A sociedade do cansaço. Rio de Janeiro: Vozes, 2015.

LATOURETTE, Audrey Wolfson. Plagiarism: Legal and Ethical Implications for the University. Journal of College and University Law, v. 37, n. 1, p. 1-91, 2010.

MARINHO, Maria Edelvacy Pinto; VARELLA, Marcelo Dias. Plágio em trabalhos acadêmicos: proposta de políticas institucionais de integridade. Revista de Políticas Públicas, Brasília, v. 5, n. 1, p. 354-365, 2015.

MARQUES, Verônica Teixeira; CARVALHO, Grasielle Borges Vieira de. Sobre a pesquisa e a produção científica na área de Direito: algumas questões para reflexão. In: PORTO, Cristiane; FERRONATO, Cristiano; LINHARES, Ronaldo. A produção científica brasileira na contemporaneidade: exigências e interlocuções. Aracaj: Edunit, 2015.

MONEBHURRUN, Nitish. Manual de Metodologia Jurídica: técnicas para argumentar em textos jurídicos. São Paulo: Saraiva, 2015.

MUNHOZ, Ana; DINIZ, Débora. Nem tudo é plágio, nem tudo é igual: infrações éticas na comunicação científica. Argumentum, Vitória, v. 3, n. 1, p. 50-55, 2011. 
Janeiro: Editora Fiocruz, 2014.

. Plágio: palavras escondidas. Brasília: LetrasLivres; Rio de

NIETZSCHE, Friedrich. Human, All Too Human: a Book for Free Spirits. Cambridge: Cambridge University Press, 1996.

OGIEN, Ruwen. L'éthique aujourd'hui: maximalistes et minimalistes. Paris: Gallimard, 2007.

OLIVEIRA, Luciano. Não fale do Código Hamurabi. A pesquisa sociojurídica na pós-graduação em Direito. In: . Sua excelência o comissário e outros ensaios de sociologia jurídica. Rio de Janeiro: Letra Legal, 2004.

POSNER, Richard. The Little Book of Plagiarism. New York: Pantheon Books, 2007.

RIBEIRO, Darcy. De fracaso a fracasso. In. Brasília: Editora UnB, 2010.

. O Brasil como problema.

RODRIGUES, Horácio Wanderlei; BORGES, Marcus Vinicius Motter. O método do caso na educação jurídica. Quaestio Juris, Rio de Janeiro, v. 9, n. 3, p. 1363-1391, 2016.

SCHOPENHAUER, Arthur. A arte de escrever. Porto Alegre: L\&PM Pocket, 2012. Fronteira, 2012.

. Do mundo como vontade e representação. Rio de Janeiro: Nova

SOUZA, Rodrigo Pagani de. Oficinas de legislação e de jurisprudência: desenvolvendo um olhar autônomo sobre Direito. In: GHIRARDI, José Garcia;

ANZELLA, Rafael Domingos Faiardo (Org.). Ensino jurídico participativo: construção de programas: experiências didáticas. São Paulo: Saraiva/FGV, 2009.

VARELLA, Marcelo Dias; MONEBHURRUN, Nitish. O que é uma boa tese de Doutorado em Direito? Uma análise a partir da própria percepção dos programas. Revista Brasileira de Políticas Públicas, Brasília, v. 10, n. 1, p. 423-443, 2013.

; ROESLER, Claudia. Dificuldades de avaliação de publicações na área do Direito. Revista Brasileira de Pós-Graduação, Brasília, v. 9, n. 18, p. 663-701, 2012.

WEBER, Max. Ciência e Política: duas vocações. São Paulo: Martin Claret, 2002.

1 Ver, por exemplo: Houaiss, Dictionário da língua portuguesa, Rio de Janeiro: Objetiva, 2003, p.302; Oxford Advanced Learner's Dictionary, Oxford: Oxford University Press, 2000, p.711; Larousse de poche 2007, Paris: Larousse, 2006, pp.437-438; Le dictionnaire encyclopédique, Paris: Hachette, vol.II, 1996, p.776.

2 Ver o Anexo 1 no final desse artigo.

3 Max Weber. Ciência e Política. Duas vocações. São Paulo: Martin Claret, 2002, pp.25-58.

4 Ver: Rodrigo Pagani de Souza, "Oficinas de legislação e de jurisprudência: desenvolvendo um olhar autônomo sobre o Direito”, in : José Garcia Ghirardi, Rafael Domingos Faiardo Vanzella (org.), Ensino 
Jurídico Participativo. Construção de Programas. Experiências didáticas, São Paulo: Saraiva/FGV, 2009, pp.113-127; Nitish Monebhurrun, Manual de Metodologia Jurídica. Técnicas para argumentar em textos jurídicos, São Paulo: Saraiva, 2015, pp.37-40.

5 Essa ideia foi desenvolvida em: Nitish Monebhurrun, Manual de Metodologia Jurídica. Técnicas para argumentar em textos jurídicos, São Paulo: Saraiva, 2015, pp.29-31. Ver também: Paulo Roberto de Almeida, "Falácias acadêmicas, 3: o mito do marco teórico", Revista Espaço Acadêmico, no.89, 2008, pp.1-5; Luciano Oliveira, "Não fale do Código Hamurabi. A pesquisa sociojurídica na pós-graduação em Direito", in, Luciano Oliveira, Sua excelência o comissário e outros ensaios de sociologia jurídica, Rio de Janeiro: Letra Legal, 2004, pp.143-145.

6 Cioran, De l'inconvénient d'être né, Paris: Gallimard (Folio-Essais), 1973, p.38.

7 Byung-Chul Han, A sociedade do cansaço. Rio de Janeiro: Editora Vozes, 2015, p.54.

8 Sobre essa questão, ver de forma geral a reflexão interessante do: Arthur Schopenhauer, A arte de escrever, Porto Alegre: L\&PM Pocket, edição de 2012, p.21.

9 Sobre o problema com a expressão de opiniões pessoais de forma geral, ver: Nietzsche, Human, All Too Human. A Book for Free Spirits, Cambridge: Cambridge University Press, 1996, pp.131-133.

10 Paulo Freire, A pedagogia do oprimido, 17a. ed., Rio de Janeiro: Paz e Terra, 1987, p.37.

11 Eis o que mostra a experiência do presente autor por ter ministrado várias aulas de metodologia jurídica em várias faculdades de Direito no Brasil.

12 Alain Finkielkraut, La défaite de la pensée, Paris: Gallimard (Folio-Essais), 1987, p.168 (Tradução livre do autor).

13 Nitish Monebhurrun, Manual de Metodologia Jurídica. Técnicas para argumentar em textos jurídicos, São Paulo: Saraiva, 2015, p.29.

14 SCHOPENHAUER, Arthur. A arte de escrever. Porto Alegre: L\&PM Pocket, 2012. p. 19.

15 Deveria, na realidade, ser o papel do colégio antes mesmo da universidade.

16 RIBEIRO, Darcy. De fracaso a fracasso. In: O Brasil como problema. Brasília: Editora UnB, 2010. p. 67.

17 Constituição Federal do Brasil, Artigo 206, inciso II.

18 Marcelo Dias Varella, Nitish Monebhurrun, "O que é uma boa tese de Doutorado em Direito? Uma análise a partir da própria percepção dos programas", Revista Brasileira de Políticas Públicas, vol.10., no.1, 2013, pp.432-433; Luciano Oliveira, "Não fale do Código Hamurabi. A pesquisa sociojurídica na pós-graduação em Direito", in, Luciano Oliveira, Sua excelência o comissário e outros ensaios de sociologia jurídica, Rio de Janeiro: Letra Legal, 2004, p.143.

19 Marcelo Dias Varella, Claudia Roesler, "Dificuldades de avaliação de publicações na área do Direito", Revista Brasileira de Pós-Graduação, vol.9, no.18., 2012, p.674.

20 Marcelo Dias Varella, Nitish Monebhurrun, "O que é uma boa tese de Doutorado em Direito? Uma análise a partir da própria percepção dos programas”, Revista Brasileira de Políticas Públicas, vol.10., no.1, 2013, p.432.

21 Marcelo Dias Varella, Nitish Monebhurrun, "O que é uma boa tese de Doutorado em Direito? Uma análise a partir da própria percepção dos programas”, Revista Brasileira de Políticas Públicas, vol.10., no.1, 2013, p.432.

22 De forma geral, ver: Carol M. Bast, Linda B. Samuels, "Plagiarism and Legal Scholarship in the Age of Information Sharing: The Need for Intellectual Honesty", Catholic University Law Review, vol. 57, 2008, pp.777-815.

23 Ver também nesse sentido: Verônica Teixeira Marques, Grasielle Borges Vieira de Carvalho, "Sobre a pesquisa e a produção científica na área de Direito: algumas questões para reflexão", in, Cristiane Porto, Cristiano Ferronato, Ronaldo Linhares, A produção científica brasileira na contemporaneidade. Exigências e Interlocuções, Aracaj: Edunit, 2015, p.167.

24 MUNHOZ, Ana; DINIZ, Débora. Nem tudo é plágio, nem tudo é igual: infrações éticas na comunicação científica. Argumentum, Vitória, v. 3, n. 1, p. 50-55, 2011. p. 52.

25 ARISTÓTELES. Éthique de Nicomaque. Paris: GF-Flammarion, 1992. p. 51.

26 ARISTÓTELES. Éthique de Nicomaque. Paris: GF-Flammarion, 1992. p. 59.

27 Ver: OLIVEIRA, Luciano. Não fale do Código Hamurabi. A pesquisa sociojurídica na pós-graduação em Direito. In: OLIVEIRA, Luciano. Sua excelência o comissário e outros ensaios de sociologia jurídica. Rio de Janeiro: Letra Legal, 2004. p. 145.

28 NIETZSCHE, Friedrich. Human, all too human: a book for free spirits. Cambridge: Cambridge University Press, 1996. p. 132. 
29 HAN, Byung-Chul. A sociedade do cansaço. Rio de Janeiro: Vozes, 2015. p. 69 et seq.

30 Lei 9.610 (19/02/1998), artigo 108.

31 Superior Tribunal de Justiça, CC 101592, 2008/0269821-5 [02/08/2010], Relator Ministro Arnaldo Esteves de Lima.

32 CONSELHO NACIONAL DE DESENVOLVIMENTO CIENTÍFICO E TECNOLÓGICO (CNPq). Relatório da Comissão de Integridade de Pesquisa do CNPq. p. 4 Disponível em: < http://www.cnpq.br/ documents/10157/a8927840-2b8f-43b9-8962-5a2ccfa74dda >.

33 POSNER, Richard. The little book of plagiarism. New York: Pantheon Books, 2007. p. 11-12; LATOURETTE, Audrey Wolfson. Plagiarism: legal and ethical implications for the university. Journal of College and University Law, v. 37, n. 1, p. 15, 2010.

34 MARINHO, Maria Edelvacy Pinto; VARELLA, Marcelo Dias. Plágio em trabalhos acadêmicos: proposta de políticas institucionais de integridade. Revista de Políticas Públicas, Brasília, v. 5, n. 1, p. 358, 2015; MUNHOZ, Ana; DINIZ, Débora. Cópia e pastiche: plágio na comunicação científica. Argumentum, v. 3, n. 1, p. 14, 2011; MUNHOZ, Ana; DINIZ, Débora. Plágio: palavras escondidas. Brasília: Letras Livres; Rio de Janeiro: Editora Fiocruz, 2014 p. 24; DUNNEWOLD, Mary. Plagiarism: proceed with caution. Student Lawyer, v. 40, n. 1, p. 17, 2011; GOUDY, Henry. Plagiarism: a fine art. The Juridical Review, v. 20, p. 302, 1909; LATOURETTE, Audrey Wolfson. Plagiarism: legal and ethical implications for the university. Journal of College and University Law, v. 37, n. 1, p. 15-18, 2010.

35 LATOURETTE, Audrey Wolfson. Plagiarism: legal and ethical implications for the university. Journal of College and University Law, v. 37, n. 1, 2010. p. 9 et seq.

36 Para alguns estudos sobre a questão do plágio, os leitores podem consultar: MARINHO, Maria Edelvacy Pinto; VARELLA, Marcelo Dias. Plágio em trabalhos acadêmicos: proposta de políticas institucionais de integridade. Revista de Políticas Públicas, Brasília, v. 5, n. 1, p. 355-365, 2015; MUNHOZ, Ana; DINIZ, Débora. Plágio: palavras escondidas. Brasília: Letras Livres; Rio de Janeiro: Editora Fiocruz, 2014. p. 193; LATOURETTE, Audrey Wolfson. Plagiarism: legal and ethical implications for the university. Journal of College and University Law, v. 37, n. 1, p. 1-91, 2010.

37 Sobre o conceito de ética minimalista, ver: OGIEN, Ruwen. L'éthique aujourd'hui: maximalistes et minimalistes. Paris: Gallimard, 2007. 252 p.

38 WEBER, Max. Ciência e política: duas vocações. São Paulo: Martin Claret, 2002. p. 114. Max Weber estabelece uma distinção entre a ética de convicção e a ética de responsabilidade da forma seguinte: "[...] oposição profunda há entre a atitude de quem se resigna às máximas da ética da convicção — diríamos, em linguagem religiosa, "O cristão cumpre seu dever e, quanto aos resultados da ação, confia em Deus" — e a atitude de quem se orienta plea ética da responsabilidade, que diz: "Devemos responder pelas previsíveis conseqüências de nossos atos". Ver também: SCHIELL, Timothy C. Using the concept of "traditional ethics" to teach introductory ethics. Teaching Ethics: The Journal of the Society for Ethics Across the Curriculum, v. 11, n. 2, p. 117.

39 Ver nesse sentido: SCHOPENHAUER, Arthur. Do mundo como vontade e representação. Rio de Janeiro: Nova Fronteira, 2012, p. 153.

40 MARINHO, Maria Edelvacy Pinto; VARELLA, Marcelo Dias. Plágio em trabalhos acadêmicos: proposta de políticas institucionais de integridade. Revista de Políticas Públicas, Brasília, v. 5, n. 1, p. 363, 2015.

41 As diretrizes encontram-se em: <http://cnpq.br/diretrizes $>$.

42 Ver: OLIVEIRA, Luciano. Não fale do Código Hamurabi: a pesquisa sociojurídica na pós-graduação em Direito. In: . Sua excelência o comissário e outros ensaios de sociologia jurídica. Rio de Janeiro: Letra Legal, 2004. p. 143-144; ALMEIDA, Paulo Roberto de. Falácias acadêmicas, 3: o mito do marco teórico. Revista Espaço Acadêmico, Maringá, n.89, p. 1-5, 2008.

43 Ver sobre essa questão: RODRIGUES, Horácio Wanderlei; BORGES, Marcus Vinicius Motter. O método do caso na educação jurídica. Quaestio Juris, Rio de Janeiro, v. 9, n. 3, p. 1367, 2016. 

INTERNET AS A RESEARCH INSTRUMENT FOR JURISTS AND ACADEMIC INTEGRITY

\begin{abstract}
This article proposes a reflection on the misuse of the Internet as a means for research work. This idea is articulated with the expected academic seriousness in legal works and it is argued that there is no intrinsic problem with the Internet, but rather with jurists' training and the lack of preparation to face the world of research activities. Undoubtedly, the Internet is a boon for the researcher. That being said, the problems related to lawyers' training and a lack of ethics in the maze towards the obtention of the law degree have converted the Internet into a pernicious tool. However, this situation also emanates from the teaching techniques of some law professors, who incite and train law students to compile documents in their works without deploying the reflection expected from a jurist. Giving in to a pernicious use of the Internet, like in cases of plagiarism, is a conundrum of ethical color but, at the same time, originates from the professional stature of law professors. This paper explains that the student's ethics during research work is a declination of the ethics of responsibility of their own professors.
\end{abstract}

Keywords: Research work. Students' training as jurists. Internet. Ethics. Acdemic Rigor.

Submetido: 16 dez. 2016

Aprovado: 23 jan. 2017 


\section{ANEXO A - Questionário enviado aos Professores das Instituições de Ensino Superior em alguns estados do Brasil.}

\begin{tabular}{|c|c|c|c|c|c|}
\hline $\begin{array}{l}\text { Estado e Cidade do(a) } \\
\text { responsável }\end{array}$ & $\begin{array}{l}\text { Os alunos sabem fazer } \\
\text { uma pesquisa jurídica } \\
\text { científica na internet? } \\
\text { Isto é, sabem buscar } \\
\text { as fontes de pesquisa } \\
\text { (textos normativos, ju- } \\
\text { risprudência, relatórios } \\
\text { e pareceres, doutrina) } \\
\text { nos sites oficiais? }\end{array}$ & $\begin{array}{l}\text { Em referência aos } \\
\text { artigos doutrinais, as } \\
\text { fontes mais consul- } \\
\text { tadas são as revistas } \\
\text { científicas pontuadas? }\end{array}$ & $\begin{array}{l}\text { Há uma tendência } \\
\text { de abusar da internet } \\
\text { durante a pesquisa ao } \\
\text { escolher os portais de } \\
\text { "facilidade" (wikipedia, } \\
\text { blogs, jus navigandi)? }\end{array}$ & $\begin{array}{l}\text { Os alunos sabem } \\
\text { dissociar entre arti- } \\
\text { gos oriundos de um } \\
\text { trabalho rigoroso de } \\
\text { pesquisa e de reflexão } \\
\text { e artigos superficiais? }\end{array}$ & $\begin{array}{l}\text { Os alunos são devi- } \\
\text { damente informados/ } \\
\text { formados para poder } \\
\text { utilizar a internet como } \\
\text { um instrumento de } \\
\text { pesquisa? }\end{array}$ \\
\hline
\end{tabular}

\begin{tabular}{|c|c|c|c|c|c|}
\hline Ceará - Fortaleza & $\begin{array}{l}\text { Parcialmente. Prati- } \\
\text { camente todos sabem } \\
\text { buscar textos de nor- } \\
\text { mas e jurisprudências. } \\
\text { Quanto à doutrina, } \\
\text { observa-se que a busca } \\
\text { é uma constante, com } \\
\text { referência a diversos } \\
\text { sites, mas por vezes a } \\
\text { qualidade/densidade } \\
\text { da doutrina pode ser } \\
\text { questionada. }\end{array}$ & $\begin{array}{l}\text { Não. Fazemos um } \\
\text { trabalho constante de } \\
\text { divulgação de portais } \\
\text { de periódicos, site do } \\
\text { CONPEDI e de outros }\end{array}$ & $\begin{array}{l}\text { Sim. O corpo docente } \\
\text { da instituição faz um } \\
\text { trabalho veemente } \\
\text { de educação e alerta } \\
\text { quanto ao cuidado } \\
\text { com as fontes utiliza- } \\
\text { das. No caso de sites } \\
\text { como JusNavigandi, } \\
\text { recomendamos que se } \\
\text { observe o currículo do } \\
\text { autor e sua titulação. }\end{array}$ & $\begin{array}{l}\text { Muitos não sabem. É } \\
\text { preciso o olhar atento } \\
\text { do orientador. Ainda } \\
\text { se vê com certa fre- } \\
\text { quência, por exemplo, } \\
\text { citações de cursos, } \\
\text { manuais e sites como } \\
\text { Âmbito Jurídico. }\end{array}$ & $\begin{array}{l}\text { Se tem realizado ao } \\
\text { longo dos anos algumas } \\
\text { atividades educativas } \\
\text { nesse sentido, sobre- } \\
\text { tudo com os alunos } \\
\text { de Projeto de TCC e } \\
\text { das disciplinas de TCC } \\
\text { e com os alunos dos } \\
\text { programas de pesqui- } \\
\text { sa. Agora em agosto } \\
\text { teremos uma atividade } \\
\text { agendada para tratar } \\
\text { desse assunto com } \\
\text { Monitores e alunos de } \\
\text { Iniciação Científica. }\end{array}$ \\
\hline Ceará - Fortaleza & $\begin{array}{l}\text { Em geral, pouco. Ten- } \\
\text { do mais a dizer "não". } \\
\text { Na universidade, por } \\
\text { meio do Nucleo de Pes- } \\
\text { quisa oferece cursos de } \\
\text { pesquisa na internet. }\end{array}$ & Não & Sim & Raramente & $\begin{array}{l}\text { Não (apesar de, como } \\
\text { disse, haver um curso, } \\
\text { que todavia é pouco di- } \\
\text { vulgado entre os alunos } \\
\text { do PPGD). }\end{array}$ \\
\hline Ceará - Fortaleza & $\begin{array}{l}\text { Não. Muitos alunos re- } \\
\text { alizam buscas em sites } \\
\text { que sistematizam e re- } \\
\text { sumem as informações }\end{array}$ & $\begin{array}{l}\text { Não. De maneira geral, } \\
\text { as buscas de artigos } \\
\text { giram em torno das pri- } \\
\text { meiras respostas apre- } \\
\text { sentadas pelo google; } \\
\text { no máximo, buscam } \\
\text { em anais de congressos, } \\
\text { como o CONPEDI. }\end{array}$ & $\begin{array}{l}\text { Sim. Estes sites com- } \\
\text { põem a maioria dos } \\
\text { resultados apresenta- } \\
\text { dos pelos alunos em } \\
\text { fase inicial de pesquisa. }\end{array}$ & $\begin{array}{l}\text { Não. Como a maioria } \\
\text { dos alunos não sabe } \\
\text { buscar artigos de quali- } \\
\text { dade, se baseia em arti- } \\
\text { gos superficiais como se } \\
\text { bons fossem. }\end{array}$ & $\begin{array}{l}\text { Não. Apesar dos es- } \\
\text { forços institucionais } \\
\text { em adquirir bases de } \\
\text { dados de qualidade, } \\
\text { whorkshops explicati- } \\
\text { vos atingem pequena } \\
\text { parcela do alunato, } \\
\text { bem como poucos pro- } \\
\text { fessores dedicam tem- } \\
\text { po de aula para explicar } \\
\text { como fazer pesquisa em } \\
\text { bases de dados. }\end{array}$ \\
\hline
\end{tabular}




\begin{tabular}{|c|c|c|c|c|c|}
\hline $\begin{array}{l}\text { Estado do Nordeste } \\
\text { - informação inespe- } \\
\text { cífica a pedido do res- } \\
\text { pondente }\end{array}$ & $\begin{array}{l}\text { Em sua grande maio- } \\
\text { ria, não. }\end{array}$ & $\begin{array}{l}\text { Há um desconhe- } \\
\text { cimento, ainda, em } \\
\text { relação à questão do } \\
\text { escalonamento de no- } \\
\text { tas do Qualis, entre } \\
\text { os alunos, e parte dos } \\
\text { professores tem uma } \\
\text { ideia genérica sobre } \\
\text { esse ranking. Na gra- } \\
\text { duação, os alunos não } \\
\text { sabem quais as revistas } \\
\text { que estão mais bem } \\
\text { pontuadas, nem qual } \\
\text { a pontuação que cada } \\
\text { estrato representa. }\end{array}$ & $\begin{array}{l}\text { Infelizmente, Jus } \\
\text { Navigandi e Wikipe- } \\
\text { dia continuam sendo } \\
\text { usados de rotina. No } \\
\text { caso da Wikipedia, os } \\
\text { orientadores reclamam } \\
\text { muito com seus alu- } \\
\text { nos, mas há quem ache } \\
\text { "normal" o uso do Jus } \\
\text { Navigandi. }\end{array}$ & $\begin{array}{l}\text { Não. Por vezes, falta } \\
\text { senso crítico e discer- } \\
\text { nimento sobre o que } \\
\text { é um trabalho de pes- } \\
\text { quisa confiável. Na } \\
\text { academia nem sempre } \\
\text { se percebe quando um } \\
\text { artigo é "opiniático" } \\
\text { - pura doxa. Pode se } \\
\text { achar normal que um } \\
\text { artigo tenha um viés } \\
\text { "advocatício" sem se } \\
\text { perceberem os grandes } \\
\text { prejuízos de se transfe- } \\
\text { rir a lógica enviesada } \\
\text { do fórum para dentro } \\
\text { da Academia. Ou seja, } \\
\text { numa pesquisa jurídica, } \\
\text { é fundamental que haja } \\
\text { dialeticidade, median- } \\
\text { te o confronto desa- } \\
\text { paixonado de muitas } \\
\text { posições discrepantes. }\end{array}$ & $\begin{array}{l}\text { A julgar pelo estágio } \\
\text { atual, creio que preci- } \\
\text { samos continuar sen- } \\
\text { sibilizando os atores } \\
\text { sociais envolvidos na } \\
\text { cena acadêmica. }\end{array}$ \\
\hline $\begin{array}{ll}\text { Distrito } & \text { Federal } \\
\text { - Brasília } & \end{array}$ & $\begin{array}{l}\text { Graduaçao- nem sem- } \\
\text { pre. Os alunos ainda } \\
\text { estão começando a } \\
\text { estagiar ou lidar com } \\
\text { tais fontes. } \\
\text { Mestrado/doutorado } \\
\text { - SIM Em geral, são } \\
\text { funcionários públicos } \\
\text { ou pesquisadores aca- } \\
\text { dêmicos que já atuam } \\
\text { com tais fontes. }\end{array}$ & $\begin{array}{l}\text { NAO. As fontes mais } \\
\text { utilizadas continuam } \\
\text { sendo livros, principal- } \\
\text { mente na graduação. } \\
\text { Talvez pela dificuldade } \\
\text { em localizar periódicos, } \\
\text { falta de informação ou } \\
\text { simplesmente tradição } \\
\text { de não procurar em } \\
\text { revistas. }\end{array}$ & $\begin{array}{l}\text { NAO, no primeiro en- } \\
\text { contro já oriento que } \\
\text { tais sites sao proibidos. }\end{array}$ & $\begin{array}{l}\mathrm{Na} \text { pós-graduacao } \\
\text { talvez, mas observo } \\
\text { que os alunos vão mais } \\
\text { para buscar artigos por } \\
\text { autores renomados do } \\
\text { que efetivamente ve- } \\
\text { rificar o conteúdo dos } \\
\text { mesmos. }\end{array}$ & $\begin{array}{l}\text { NAO. Não é oferecida } \\
\text { uma formação para os } \\
\text { alunos nesse sentido } \\
\text { nem na graduação nem } \\
\text { na pós graduacão }\end{array}$ \\
\hline $\begin{array}{l}\text { Distrito Federal - } \\
\text { Brasília }\end{array}$ & $\begin{array}{l}\text { Sim, entretanto muitos } \\
\text { ainda precisam do au- } \\
\text { xílio do professor. }\end{array}$ & $\begin{array}{l}\text { Não, as fontes mais } \\
\text { consultadas são re- } \\
\text { tiradas de pesquisas } \\
\text { simples na Internet. }\end{array}$ & $\begin{array}{l}\text { Sim, principalmente jus } \\
\text { Navigandi e blogs. }\end{array}$ & Não, definitivamente. & $\begin{array}{l}\text { Depende muito do pro- } \\
\text { fessor para informação. } \\
\text { Formação acredito que } \\
\text { não. }\end{array}$ \\
\hline
\end{tabular}

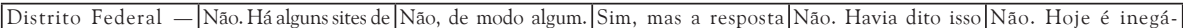
doutrina que são fre- Em quinze anos como não pode ser tão ca- anteriormente (per- vel que o aluno sabe quentemente visitados professor, orientando tegórica, pois depende gunta 1). Acredito que utilizar a Internet, o (Jota, Jus navigandi, e participando de inú- do tema. Se o tema for eles ainda nem pos- problema é utilizá-la Ambito jurídico etc.), meras bancas de TCC, geral, percebo o uso de suem a capacidade de para fins acadêmicos. o que talvez se expli- raramente vi citações manuais; já quando o realizar tal avaliação. Não há, nas faculdaque pela quantidade de revistas científicas. assunto é mais espe- Compete, portanto, des, laboratórios para de artigos disponíveis Este é um problema da cífico, aí a Internet se aos professores, guiá- que o aluno aprenda a em tais endereços. Há academia brasileira de torna a fonte princi- -los, indicando autores fazer uma boa pesquisa. artigos de qualidade um modo geral, não pal. Quanto ao uso do e artigos de qualidade e artigos ruins, e os dos alunos. Professores Wikipédia, acredito para temas específicos. alunos definitivamen- não leem tais revistas. que os próprios alunos te não sabem como Isso talvez se explique possuem certo receio diferenciá-los, o que pela baixíssima quali- em utilizá-lo, então é normal, já que estão dade de alguns artigos não vejo muita citação em processo de apren- publicados, mesmo em desta fonte nos trabadizado. Quanto à juris- revistas com a mais lhos que leio. prudência, os alunos de alta pontuação. Engraduação não sabem tretanto, há algumas como pesquisar. disciplinas em que a consulta a revistas é mais constante, como Direito do Trabalho, por exemplo (publicação da RT, que não sei nem se é qualificada!) 


\begin{tabular}{|c|c|c|c|c|c|}
\hline Minas Gerais - Unaí & $\begin{array}{l}\text { Não. Um dos proble- } \\
\text { mas que mais enfrenta- } \\
\text { mos aqui é a utilização } \\
\text { de fontes com pouco } \\
\text { ou quase nenhum valor } \\
\text { científico. }\end{array}$ & $\begin{array}{l}\text { Não. A maioria dos } \\
\text { artigos utilizados pe- } \\
\text { los acadêmicos são de } \\
\text { revistas sem qualifi- } \\
\text { cação, nem mesmo } \\
\text { reconhecimento de } \\
\text { autoria e relevância. } \\
\text { Representa um grande } \\
\text { problema enfrentado } \\
\text { desde o primeiro pe- } \\
\text { ríodo pela Instituição } \\
\text { com a realização de } \\
\text { artigos científicos pelos } \\
\text { acadêmicos. }\end{array}$ & $\begin{array}{l}\text { Sim. Os acadêmicos } \\
\text { insistem em realizar } \\
\text { pesquisas em locais } \\
\text { com pouquíssima ou } \\
\text { nenhuma credibilida- } \\
\text { de, inclusive para a } \\
\text { coleta de jurisprudên- } \\
\text { cias, muitas vezes não } \\
\text { sabem nem acessar os } \\
\text { sites dos tribunais. }\end{array}$ & $\begin{array}{l}\text { Não. Preferem a facili- } \\
\text { dade de encontrar ma- } \\
\text { terial mais acessível e } \\
\text { com primeira busca nos } \\
\text { sites, sem verificação } \\
\text { de autoria e de origem } \\
\text { das informações. }\end{array}$ & $\begin{array}{l}\text { Sim. A Instituição, há } \\
\text { aproximadamente } 03 \\
\text { (três) anos, implantou, } \\
\text { a nível global, a prática } \\
\text { de atividades de inicia- } \\
\text { ção cientifica com os } \\
\text { acadêmicos, realizando } \\
\text { uma Mostra Científica } \\
\text { a cada ano. Os acadê- } \\
\text { micos são incentivados } \\
\text { à realização de artigos } \\
\text { e ao longo do curso } \\
\text { busca-se direcioná-los } \\
\text { os mesmos para a uti- } \\
\text { lização de artigos de } \\
\text { relevância e com fontes } \\
\text { cada vez mais confiá- } \\
\text { veis. Percebe-se uma } \\
\text { melhora na atuação } \\
\text { dos acadêmicos à medi- } \\
\text { da que são informados } \\
\text { da existências destas } \\
\text { fontes não seguras }\end{array}$ \\
\hline
\end{tabular}

\begin{tabular}{|c|c|c|c|c|c|}
\hline $\begin{array}{l}\text { Minas Gerais - Pa- } \\
\text { racatu }\end{array}$ & $\begin{array}{l}\text { Não. Porque não são } \\
\text { preparados para a cita- } \\
\text { da atividade. }\end{array}$ & $\begin{array}{l}\text { Sim. Porque estão à } \\
\text { disposição na biblio- } \\
\text { teca e usam as mais } \\
\text { conhecidas. }\end{array}$ & $\begin{array}{l}\text { Sim. Pela facilidade e } \\
\text { falta de interesse de } \\
\text { buscar conhecimento. }\end{array}$ & $\begin{array}{l}\text { Sim. Pela dificuldade } \\
\text { de entendimento do } \\
\text { primeiro. }\end{array}$ & $\begin{array}{l}\text { Sim. Dando inclusive } \\
\text { opçôes de biblioteca } \\
\text { virtual. }\end{array}$ \\
\hline $\begin{array}{l}\text { Minas Gerais - Patos } \\
\text { de Minas }\end{array}$ & $\begin{array}{l}\text { Sim, apesar de não } \\
\text { serem adeptos do for- } \\
\text { malismo acadêmico, } \\
\text { possuímos um sistema } \\
\text { com vasta base de da- } \\
\text { dos e eventualmente } \\
\text { necessitam buscar } \\
\text { conteúdos sobre de- } \\
\text { terminada disciplina. }\end{array}$ & $\begin{array}{l}\text { Sim, no caso do UNI- } \\
\text { PAM o portal vLex é } \\
\text { o mais utilizado, em } \\
\text { segundo RT Online. }\end{array}$ & $\begin{array}{l}\text { Sim, o que dificulta o } \\
\text { aprofundamento de } \\
\text { conteúdos, e os ins- } \\
\text { truímos a evitar tais } \\
\text { ferramentas }\end{array}$ & $\begin{array}{l}\text { Poucos alunos conse- } \\
\text { guem, e são sempre os } \\
\text { que possuem tendência } \\
\text { à vida acadêmica. }\end{array}$ & $\begin{array}{l}\text { Sim, e são estimulados } \\
\text { a usar várias bases de } \\
\text { dados, sempre as que } \\
\text { possuem maior peso } \\
\text { em cada disciplina, } \\
\text { no UNIPAM eles têm } \\
\text { acesso via portal aca- } \\
\text { dêmico à RT Online, } \\
\text { Saraiva, vLex, Editora } \\
\text { Fórum, Minha Biblio- } \\
\text { teca, e o sistema de } \\
\text { publicações EBSCO. }\end{array}$ \\
\hline Paraná - Curitiba & $\begin{array}{l}\text { Não. De um modo } \\
\text { geral desconhecem } \\
\text { revistas eletrônicas e } \\
\text { chegam mesmo a citar } \\
\text { o Wikipedia }\end{array}$ & $\begin{array}{l}\text { Não. Desconhecem a } \\
\text { utilidade e até mesmo } \\
\text { a existência de artigos } \\
\text { e revistas. }\end{array}$ & $\begin{array}{l}\text { Sim. Buscam "entre- } \\
\text { gar" um trabalho e } \\
\text { não aprender com a } \\
\text { pesquisa. }\end{array}$ & $\begin{array}{l}\text { Desconhecem por } \\
\text { completo. Chegam } \\
\text { mesmo a citar em seus } \\
\text { trabalhos livros de "re- } \\
\text { sumos" }\end{array}$ & $\begin{array}{l}\text { Sim, mas acham que é } \\
\text { desnecessário. }\end{array}$ \\
\hline Paraná - Maringá & Não. & $\begin{array}{l}\text { Não. No geral os alu- } \\
\text { nos não sabem quais } \\
\text { são as revistas mais } \\
\text { "pontuadas". É preciso } \\
\text { ensiná-los a buscar es- } \\
\text { sas fontes. }\end{array}$ & Sim. & Não. & $\begin{array}{l}\text { Não. Mesmo os cursos } \\
\text { promovidos pela facul- } \\
\text { dade deixam a desejar. }\end{array}$ \\
\hline Pará - Belém & $\begin{array}{l}\text { Sim, a Universidade } \\
\text { tem livre acesso ao } \\
\text { portal de periódicos } \\
\text { da CAPES, além de } \\
\text { site oficiais }\end{array}$ & $\begin{array}{l}\text { Não tenho essa in- } \\
\text { formação }\end{array}$ & $\begin{array}{l}\text { Não tenho essa in- } \\
\text { formação }\end{array}$ & $\begin{array}{l}\text { Sim, buscam identifi- } \\
\text { car a confidencialida- } \\
\text { de da fonte }\end{array}$ & Sim. \\
\hline
\end{tabular}




\begin{tabular}{|c|c|c|c|c|c|}
\hline Piauí - Teresina & $\begin{array}{l}\text { Depende, dou aula } \\
\text { em duas instituições } \\
\text { completamente dife- } \\
\text { rentes institucional- } \\
\text { mente, em uma delas, } \\
\text { a maioria dos alunos } \\
\text { de graduação conse- } \\
\text { guem ter uma noção } \\
\text { boa de uma pesquisa } \\
\text { de qualidade, já na } \\
\text { outra IES a maioria } \\
\text { tem um conhecimen- } \\
\text { to e habilidade baixa } \\
\text { sobre o assunto, dei- } \\
\text { xando a desejar. }\end{array}$ & $\begin{array}{l}\text { Não, via de regra os } \\
\text { artigos são aqueles en- } \\
\text { contrados nas fontes } \\
\text { de acesso aberto na } \\
\text { internet. Não impor- } \\
\text { tando o conceito de } \\
\text { tal revista. }\end{array}$ & $\begin{array}{l}\text { Há, percebe-se com } \\
\text { mais facilidade em } \\
\text { uma IES, já em outra } \\
\text { é raro esse tipo de } \\
\text { referência. }\end{array}$ & $\begin{array}{l}\text { Sim, sabem diferen- } \\
\text { ciar, porém não se } \\
\text { preocupam em citar } \\
\text { os superficiais. }\end{array}$ & $\begin{array}{l}\text { Sim, pelo menos nas } \\
\text { minhas aulas eu apre- } \\
\text { sento boas revistas } \\
\text { e sites de pesquisa } \\
\text { confiáveis. }\end{array}$ \\
\hline $\begin{array}{l}\text { Rio de Janeiro - Rio } \\
\text { de Janeiro }\end{array}$ & $\begin{array}{l}\text { Não. E acho muito } \\
\text { controverso chamar } \\
\text { de pesquisa cien- } \\
\text { tífica a tradicional } \\
\text { busca exaustiva pelas } \\
\text { "fontes" do Direito. } \\
\text { Dogmática, ainda que } \\
\text { bem feita, não é ciên- } \\
\text { cia. Outra questãosão } \\
\text { os sites oficiais: ainda } \\
\text { que dominemos os } \\
\text { processos de constru- } \\
\text { ção, manutenção e } \\
\text { tratamento das bases } \\
\text { que eles disponibi- } \\
\text { lizam - o que não } \\
\text { fazemos - é muito } \\
\text { duvidosa sua capaci- } \\
\text { dade de nos fornecer } \\
\text { subsídios para uma } \\
\text { pesquisa de caráter } \\
\text { científico. }\end{array}$ & $\begin{array}{l}\text { Não. Em parte porque } \\
\text { não possuem treina- } \\
\text { mento para tratar } \\
\text { a "doutrina" como } \\
\text { bibliografia, ou uma } \\
\text { "tese" como um pro- } \\
\text { blema de pesquisa. } \\
\text { Noutra parte, porque } \\
\text { a área de Direito é } \\
\text { assaz ineficiente na } \\
\text { atividade de inde- } \\
\text { xação e organização } \\
\text { de periódicos de alto } \\
\text { nível. }\end{array}$ & $\begin{array}{l}\text { Sim. O Google ainda } \\
\text { é a mais utilizada fer- } \\
\text { ramenta de busca, e a } \\
\text { baixa cientificidade } \\
\text { da área bloqueia nos } \\
\text { alunos a capacidade } \\
\text { de distinguir entre a } \\
\text { literatura científica e } \\
\text { as "fontes cinzentas". }\end{array}$ & $\begin{array}{l}\text { Não. Raramente re- } \\
\text { cebem formação me- } \\
\text { todológica multidis- } \\
\text { ciplinar, muito menos } \\
\text { habilidade para reco- } \\
\text { nhecer tratamento } \\
\text { de dados quais sejam. } \\
\text { São advogados da } \\
\text { própria hipótese. }\end{array}$ & $\begin{array}{l}\text { Não. E a Internet } \\
\text { também não se apre- } \\
\text { senta ainda como fer- } \\
\text { ramenta privilegiada } \\
\text { para tanto. Poucas } \\
\text { são as pesquisas cujas } \\
\text { fontes estão ampla- } \\
\text { mente disponibiliza- } \\
\text { das online. }\end{array}$ \\
\hline
\end{tabular}




\begin{tabular}{|c|c|c|c|c|c|}
\hline Rio de Janeiro & $\begin{array}{l}\text { Sim. Os alunos con- } \\
\text { seguem localizar as } \\
\text { fontes de que necessi- } \\
\text { tam para realizar suas } \\
\text { pesquisas. }\end{array}$ & $\begin{array}{l}\text { Não. A pontuação da } \\
\text { revista no Qualis é } \\
\text { menos relevante que } \\
\text { o renome da institui- } \\
\text { ção de origem. }\end{array}$ & $\begin{array}{l}\text { Não. Os portais de } \\
\text { facilidades são pouco } \\
\text { prestigiados por serem } \\
\text { considerados pouco } \\
\text { confiáveis e mal vistos } \\
\text { como referências. }\end{array}$ & $\begin{array}{l}\text { Sim. Embora o crité- } \\
\text { rio para a seleçẫo de } \\
\text { material seja mais im- } \\
\text { pactado pelo viés do } \\
\text { pesquisador que pelas } \\
\text { referências ou evidên- } \\
\text { cias disponíveis. }\end{array}$ & $\begin{array}{l}\text { Não. A instituição } \\
\text { espera que esses co- } \\
\text { nhecimentos já se- } \\
\text { jam dominados pelos } \\
\text { alunos. }\end{array}$ \\
\hline $\begin{array}{l}\text { Rio Grande do Sul - } \\
\text { Porto Alegre }\end{array}$ & $\begin{array}{l}\text { Sim. Não creio que } \\
\text { isso seja um problema } \\
\text { para os nossos alunos. } \\
\text { Quando eu lecionava } \\
\text { metodologia de pes- } \\
\text { quisa, eu ensinava } \\
\text { tudo isso aos alunos, } \\
\text { e imagino que o atual } \\
\text { professor da disciplina } \\
\text { também o faça. }\end{array}$ & $\begin{array}{l}\text { Não necessariamente. } \\
\text { Acredito que isso seja } \\
\text { mais uma preocupa- } \\
\text { ção dos alunos da pós- } \\
\text {-graduação. Acredito } \\
\text { que na graduação a } \\
\text { pontuação das revis- } \\
\text { tas não seja levada } \\
\text { em conta. }\end{array}$ & $\begin{array}{l}\text { Não, esses sites não } \\
\text { são citados pelos meus } \\
\text { alunos. }\end{array}$ & $\begin{array}{l}\text { Depende do nível de } \\
\text { desenvolvimento do } \\
\text { aluno. Certamente } \\
\text { os alunos de primeiro } \\
\text { ano de Faculdade não } \\
\text { conseguem, mas nos } \\
\text { semestres mais avan- } \\
\text { çados essa reflexão } \\
\text { se torna possível. Em } \\
\text { nível de graduação, } \\
\text { gostaria de fazer uma } \\
\text { distinção entre alu- } \\
\text { nos que se engajam } \\
\text { em grupos de pes- } \\
\text { quisa versus aqueles } \\
\text { que não o fazem. Os } \\
\text { alunos do primeiro } \\
\text { grupo são muito mais } \\
\text { aptos para fazer es- } \\
\text { sas dissociações. Na } \\
\text { pós-graduação, este } \\
\text { tipo de dissociação é } \\
\text { certamente espera- } \\
\text { do. Sua capacidade } \\
\text { de fazê-lo dependerá } \\
\text { da formação de base } \\
\text { (curso de graduação) } \\
\text { do aluno de mestrado. }\end{array}$ & $\begin{array}{l}\text { Tenho conhecimento } \\
\text { de que a biblioteca da } \\
\text { Universidade oferece } \\
\text { cursos de treinamen- } \\
\text { to, assim como em- } \\
\text { presas tipo Westlaw, } \\
\text { que também oferecem } \\
\text { treinamentos. }\end{array}$ \\
\hline
\end{tabular}




\begin{tabular}{|c|c|c|c|c|c|}
\hline $\begin{array}{l}\text { Rio Grande do Sul - } \\
\text { Porto Alegre }\end{array}$ & $\begin{array}{l}\text { Sim, os alunos sabem, } \\
\text { quando atingem a fase } \\
\text { em que é oferecida } \\
\text { a minha disciplina, } \\
\text { fazer uma pesquisa } \\
\text { jurídica científica na } \\
\text { Internet, ou possuem } \\
\text { facilmente acesso à } \\
\text { informação de como } \\
\text { se faz isso, seja com } \\
\text { consulta a colegas ou } \\
\text { com apoio da biblio- } \\
\text { tecária da IES e os } \\
\text { recursos de Internet } \\
\text { que a biblioteca ofere- } \\
\text { ce. No mais, com uma } \\
\text { simples orientação do } \\
\text { professor, conseguem } \\
\text { potencializar a busca, } \\
\text { uma vez que pode o } \\
\text { professor indicar sites } \\
\text { ou bancos de dados } \\
\text { a tanto. Já os alunos } \\
\text { de pós-graduação es- } \\
\text { tão mais experientes } \\
\text { ainda em tais buscas. } \\
\text { Todavia, tal experi- } \\
\text { ência vem mais de } \\
\text { conversas com deter- } \\
\text { minados professores e } \\
\text { determinados colegas } \\
\text { de aula, do que por } \\
\text { uma capacitação ofe- } \\
\text { recida pelo curso. }\end{array}$ & $\begin{array}{l}\text { Não, as fontes mais ci- } \\
\text { tadas são ainda livros } \\
\text { e capítulos de livros } \\
\text { disponíveis em meios } \\
\text { físicos ou na internet, } \\
\text { mas não tanto artigos } \\
\text { de revistas disponí- } \\
\text { veis na Internet. Os } \\
\text { alunos ainda não se } \\
\text { pautam em revistas } \\
\text { eletrônicas pontua- } \\
\text { das, por não terem } \\
\text { clara essa métrica das } \\
\text { pontuações, por um } \\
\text { lado, e por terem ain- } \\
\text { da certo preconceito } \\
\text { frente às informações } \\
\text { obtidas na Internet } \\
\text { - preconceito esse } \\
\text { ainda alimentado } \\
\text { por orientadores e } \\
\text { pesquisadores mais } \\
\text { tradicionais. Já na } \\
\text { pós-graduação, o sis- } \\
\text { tema Qualis é mais } \\
\text { difundido e é levado } \\
\text { em conta parcialmen- } \\
\text { te para a citação de } \\
\text { uma revista. Eu diria, } \\
\text { contudo, que o tema } \\
\text { do artigo ainda tem } \\
\text { mais relevância do } \\
\text { que a pontuação da } \\
\text { revista em que ele foi } \\
\text { citado, para receber } \\
\text { uma eventual citação } \\
\text { em um trabalho aca- } \\
\text { dêmico. }\end{array}$ & $\begin{array}{l}\text { Não, na IES em que } \\
\text { atuo, não vejo essa } \\
\text { tendência, até por- } \\
\text { que o orientador em } \\
\text { algum contato sem- } \\
\text { pre abordará a impro- } \\
\text { priedade de consultas } \\
\text { assim, tão livres e } \\
\text { sem parâmetros, na } \\
\text { Internet, e abordará } \\
\text { o inconveniente de ci- } \\
\text { tações assim em bases } \\
\text { tão frágeis cientifica- } \\
\text { mente. Todavia, pode } \\
\text { que um artigo com } \\
\text { título e abordagem } \\
\text { interessante, publi- } \\
\text { cado em tais sites, } \\
\text { sejam usados como } \\
\text { uma referência inicial } \\
\text { de investigação. }\end{array}$ & $\begin{array}{l}\text { Sim, os alunos sabem, } \\
\text { e mais ainda sabem } \\
\text { os de pós-graduação. } \\
\text { Todavia, muitos são } \\
\text { atraídos a um artigo } \\
\text { pelo seu título e pela } \\
\text { possibilidade de esse } \\
\text { artigo sustentar uma } \\
\text { tese sua, e não tanto } \\
\text { pelo trabalho rigoroso } \\
\text { de pesquisa que ele } \\
\text { ensejou. }\end{array}$ & $\begin{array}{l}\text { Não, não vejo em } \\
\text { minha IES um esfor- } \\
\text { ço institucional para } \\
\text { tanto. Eventualmen- } \\
\text { te, aparece um co- } \\
\text { merciante de alguma } \\
\text { revista ou de algum } \\
\text { site promovendo um } \\
\text { seminário e tal. Penso } \\
\text { que os alunos apren- } \\
\text { dem tais técnicas ou } \\
\text { com algum orienta- } \\
\text { dor comprometido } \\
\text { ou com os próprios } \\
\text { colegas. }\end{array}$ \\
\hline
\end{tabular}




\begin{tabular}{|c|c|c|c|c|c|}
\hline $\begin{array}{l}\text { Rondônia - Porto } \\
\text { Velho }\end{array}$ & $\begin{array}{l}\text { Em geral, quanto à ju- } \\
\text { risprudência e textos } \\
\text { normativos os alunos } \\
\text { estão habituados a } \\
\text { fazer essas buscas na } \\
\text { internet, até mesmo } \\
\text { em razão dos estágios } \\
\text { que fazem. Noto que a } \\
\text { grande dificuldade diz } \\
\text { respeito à doutrina. } \\
\text { Ainda há uma visão } \\
\text { muito manualesca } \\
\text { na graduação, assim } \\
\text { estão acostumados em } \\
\text { pesquisar em livros, } \\
\text { desconhecendo, na } \\
\text { maioria das vezes, os } \\
\text { repositórios de artigos } \\
\text { científicos de qualida- } \\
\text { de e como procurá-los } \\
\text { na internet. Algumas } \\
\text { vezes citam artigos de } \\
\text { pouco reconhecimen- } \\
\text { to científico como jus } \\
\text { navigandi e outros. }\end{array}$ & $\begin{array}{l}\text { Os alunos, em ge- } \\
\text { ral, desconhecem o } \\
\text { sistema de pontu- } \\
\text { ação QUALIS dos } \\
\text { periódicos, então não } \\
\text { buscam artigos com } \\
\text { base nesse sistema } \\
\text { de pontuação. Os } \\
\text { artigos citados são } \\
\text { aqueles facilmente } \\
\text { achados pelo google, } \\
\text { sem maior cuidado } \\
\text { quanto à qualidade } \\
\text { da fonte. }\end{array}$ & $\begin{array}{l}\text { Sim, é o mais fácil } \\
\text { para os acadêmicos, } \\
\text { então, acaba sendo a } \\
\text { fonte mais usada. }\end{array}$ & $\begin{array}{l}\text { Em geral, não. Os alu- } \\
\text { nos citam o que for es- } \\
\text { pecífico quanto ao seu } \\
\text { tema, sem se atentar } \\
\text { para a qualidade da } \\
\text { pesquisa feita. Na sua } \\
\text { maioria desconhecem } \\
\text { o diferencial entre } \\
\text { algo superficial e um } \\
\text { estudo aprofundado. }\end{array}$ & $\begin{array}{l}\text { Nas aulas de meto- } \\
\text { dologia o professor } \\
\text { ensina as ferramentas } \\
\text { de busca científicas } \\
\text { disponíveis, mostran- } \\
\text { do as fontes confiáveis } \\
\text { de artigos científicos } \\
\text { na internet. Da mes- } \\
\text { ma forma o professor } \\
\text { orientador faz essas } \\
\text { ponderações durante } \\
\text { a orientação. }\end{array}$ \\
\hline $\begin{array}{l}\text { São Paulo - São } \\
\text { Paulo }\end{array}$ & $\begin{array}{l}\text { Sim, os alunos têm } \\
\text { bastante facilidade. A } \\
\text { dificuldade me parece } \\
\text { estar em separar o } \\
\text { que é material rele- } \\
\text { vante (boa fonte de } \\
\text { conhecimento, boa } \\
\text { qualidade) de artigos } \\
\text { com menos importân- } \\
\text { cia científica. }\end{array}$ & $\begin{array}{l}\text { Não. Em geral, os } \\
\text { alunos não recorrem } \\
\text { à pontuação como } \\
\text { referência de quali- } \\
\text { dade. Autores "co- } \\
\text { nhecidos", "notórios" } \\
\text { são os mais citados } \\
\text { - independentemente } \\
\text { da fonte. }\end{array}$ & $\begin{array}{l}\text { Sim. Revista Conjur } \\
\text { tem se tornado refe- } \\
\text { rencia - notadamen- } \\
\text { te, artigos curtos de } \\
\text { doutrinadores mais } \\
\text { tradicionais. Há, con- } \\
\text { tudo, boas exceções. }\end{array}$ & $\begin{array}{l}\text { Dificilmente. O crité- } \\
\text { rio é ainda "notorie- } \\
\text { dade" de pareceristas } \\
\text { (e não pesquisadores, } \\
\text { mais propriamente). } \\
\text { Há, contudo, boas } \\
\text { exceções. }\end{array}$ & $\begin{array}{l}\text { Não suficientemente. } \\
\text { Cursos de metodo- } \\
\text { logia e orientadores } \\
\text { que trazem essa pro- } \\
\text { blemática costumam } \\
\text { ser exceção. }\end{array}$ \\
\hline
\end{tabular}

